\title{
Heme Iron Polypeptide in Iron Deficiency Anemia of Pregnancy: Current Evidence*
}

\author{
Bhaskar Pal1, Hemant Deshpande², Tripura Sundari'3 , Parag Biniwale"4, Kamlesh Shah", \\ Sugandh Goel ${ }^{6}$, Amandeep Singh Khurana $^{6}$, Amit Qamra $^{6}$, Salman Motlekar ${ }^{6 \#, ~ H a n m a n t ~ B a r k a t e ~}{ }^{6}$
}

\author{
${ }^{1}$ Department of Obstetrics \& Gynecology, Apollo Gleneagles Hospital Ltd., Kolkata, India \\ ${ }^{2}$ Department of Obstetrics \& Gynecology, Dr D.Y. Patil Medical College \& Hospital, Pune, India \\ ${ }^{3}$ Department of Obstetrics \& Gynecology, Krishna Institute of Medical Sciences, Secunderabad, India \\ ${ }^{4}$ Department of Obstetrics \& Gynecology, Biniwale Clinic, Pune, India \\ ${ }^{5}$ Department of Obstetrics \& Gynecology, Sahyadri Hospital, Karad, India \\ ${ }^{6}$ Department of Medical Affairs, Wockhardt Limited, Mumbai, India \\ Email: palbas@hotmail.com,drhemantdeshpande@gmail.com,drsundari@gmail.com,parag.biniwale@gmail.com, \\ kamleshcs@gmail.com, "smotlekar@wockhardt.com
}

How to cite this paper: Pal, B., Deshpande, H., Sundari, T., Biniwale, P., Shah, K., Goel, S., Khurana, A.S., Qamra, A., Motlekar, S. and Barkate, H. (2017) Heme Iron Polypeptide in Iron Deficiency Anemia of Pregnancy: Current Evidence. Open Journal of Obstetrics and Gynecology, 7, 420-431.

https://doi.org/10.4236/ojog.2017.74044

Received: March 20, 2017

Accepted: April 18, 2017

Published: April 21, 2017

Copyright ( 92017 by authors and Scientific Research Publishing Inc. This work is licensed under the Creative Commons Attribution International License (CC BY 4.0).

http://creativecommons.org/licenses/by/4.0/

\begin{abstract}
Iron deficiency is the most common nutritional deficiency leading to anemia in pregnancy. Conventionally, non-heme form of iron salts has been the mainstay of treatment. However, patient compliance is an important concern with existing oral iron therapy due to gastrointestinal side effects. Heme iron, a better bioavailable and tolerable form of iron can be suitable form of iron for supplementation in pregnancy. Evidence suggests its utility in pregnancy for treatment of iron deficiency anemia with benefits extending to postpartum period. Effective transfer across placenta to fetus further supports its utility in pregnancy. This review discusses in details the absorption kinetics along with clinical evidence on efficacy, safety, and tolerability of heme-iron supplementation in iron deficiency anemia of pregnancy.
\end{abstract}

\section{Keywords}

Heme Iron, Pregnancy, Iron Absorption, Iron Deficiency, Anemia

\section{Introduction}

Anemia is a condition of red blood cells' insufficiency hampering their oxygen-carrying capacity to suffice body's physiologic needs. Age, gender, altitude of residence, smoking behavior and pregnancy govern physiologic needs. Iron deficiency is thought to be the most common cause of anemia among other nutritional deficiencies like vitamin B12, folic acid and vitamin A [1]. Iron requirements during pregnancy are significantly higher as compared to the 
non-pregnant women. The replenishment of this iron requirement depends on size of the iron stores at the start of pregnancy and the amount of dietary iron absorbed during pregnancy. Increased demand of the iron rises during the second trimester and then continues to increase steadily in the third trimester, puerperal phase and during the first few months postpartum [2].

Anemia in pregnancy has an impact on maternal and fetal health. High maternal mortality and morbidity, preterm delivery, low birth weight and inferior neonatal health are documented adverse effects of latter which highlight upon iron supplementation during pregnancy essentially from second trimester till early post-partum period [3] [4] [5] [6].

Oral iron therapy is the most cost-effective and safe therapy for iron deficiency anemia (IDA) in pregnancy. Various shortcomings exist with conventional non-heme iron preparations like administration only on empty stomach, gastric discomfort, constipation, varying bioavailability of diverse salts, and drug and food interactions tend to adversely affect compliance with treatment [6] [7]. Heme iron (animal based iron source) utilization is significantly higher than non-heme iron [8]. Further, a lower amount of heme iron is needed to supplement iron on the daily basis and is thus better tolerated than non-heme iron supplements [9] [10]. As intolerance and hence non-compliance to non-heme iron may limit its efficacy during pregnancy [6], use of heme iron supplement will be helpful to improve adherence to therapy and achieve continued therapy throughout the pregnancy. Given these advantages with heme iron, this article covers detailed review of heme iron supplement in management of IDA of pregnancy.

\section{Anemia in Pregnancy}

Anemia is defined as hemoglobin concentration $(\mathrm{Hb})<2$ standard deviations below the mean for a healthy matched population. However, there is variation in what are considered normal values for pregnancy [6]. World Health Organization (WHO) [1] and Indian [5] guidelines define anemia in pregnancy as hemoglobin concentration of $<11.0 \mathrm{~g} / \mathrm{dl}$. Hemoglobin concentration changes dramatically during pregnancy to accommodate the increasing maternal blood volume and the iron needs of the fetus. Because of the compensatory mechanism anemia becomes clinically apparent only when iron deficiency state is quite advanced [1].

Prevalence of anemia in India is 53.6\% (year 2011) as per world bank data which is almost unchanged over a decade (55\% in year 2000) [11]. Recent studies have shown variation in the prevalence of anemia among pregnant women across India from $100 \%$ to $89.6 \%$ [12] [13]. Iron deficiency being the most common cause of anemia, adequate and effective supplementation with iron is crucial to reduce maternal and fetal morbidity and mortality [9].

\section{Iron Homeostasis in the Pregnancy}

Pregnancy is a state characterized by numerous functional hematological changes. Dilutional anemia develops during pregnancy because of disproportio- 
nate increase in the total blood volume and red cell mass [14]. Iron requirement increases gradually with $0.8 \mathrm{mg} /$ day in the first trimester to $7.5 \mathrm{mg} /$ day in third trimester. Absorption of iron increases with increasing duration of gestation with a peak at around 20th week of gestation. Non-pregnant women have a median dietary iron intake of $\sim 9 \mathrm{mg}$ /day, suggesting that over $90 \%$ of women have an intake below the recommended $12-18 \mathrm{mg} /$ day [4]. Given the high requirements of iron in pregnancy $(35 \mathrm{mg} /$ day as recommended by National Institute of Nutrition, Hyderabad, India) [15], dietary iron alone is insufficient to maintain iron and thus hemoglobin levels. Hence, conventional iron supplementation is recommended routinely in the pregnancy [1] [5] [13]. Changes in the hormonal milieu affect gastrointestinal (GI) system leading to nausea, heartburn, constipation. Routine oral iron supplementation containing conventional non-heme iron in the second and third trimester tends to aggravate GI disturbances [16]. Thus, heme iron is considered to be a better option for iron supplementation.

\section{Heme Iron}

\subsection{Background and Chemistry}

Dietary iron is contained in two forms namely non-heme and heme. Though heme contributes to a minor portion, its bioavailability is better as compared to non-heme iron [10] [17]. Commercially, heme iron is available as heme iron polypeptide (HIP) for oral supplementation. In HIP, the heme porphyrin ring is utilized to supply iron to the sites of absorption. HIP represents a promising strategy for supplementation of iron with higher bioavailability and lower gastrointestinal irritability [18]. HIP is produced by hydrolysis of animal source hemoglobin with proteolytic enzymes. Digestion conditions, enzymes used, and drying method alters the properties of heme-iron [19]. The technique used for synthesis of HIP leaves the peptides from the hemoglobin subunits covalently bound to the heme ring. This increases solubility at low $\mathrm{pH}$ [10]. Solubility of heme iron governs its binding to heme receptor and transport into the cell which is reflected in achievement of higher bioavailability. Compared to non-heme iron, a 10 times higher bioavailability of heme iron have been reported in normal volunteers [20].

Non-selective iron channels called divalent metal transporters assist in the transport of iron salts into the body. Besides, this iron channel is not regulated, which means that the iron salt intake needs to be strictly controlled to avoid iron overload. Unlike, iron salts regulation of absorption of heme iron polypeptide does occur through receptors. Thus, continuous supplementation does not lead to iron overload [19].

\subsection{Absorption Kinetics}

DMT1 (divalent metal transporter 1) at the microvillus membrane of the enterocytes allows uptake of non-heme iron. Ferric iron is reduced to ferrous form by duodenal cytochrome b protein (DCytB) present in enterocyte membrane. Absorbed iron joins the labile iron pool inside the enterocyte. From this labile 
pool, ferrous iron is absorbed into the bloodstream via ferroportin (FPN1) transporter which is again oxidized to ferric form. The ferric iron then binds to apo-transferrin and is transported in blood. Heme iron absorption is postulated to be by two mechanisms (Figure 1). In the first mechanism, heme iron is taken up by heme transporter protein coupled folate transfer/heme carrier protein 1 (PCFT/HCP1) directly into the cytoplasm of enterocyte. The intact heme is then transported across basolateral membrane by cell surface receptor for feline leukemia virus subgroup C (FLVCR) protein and then binds to hemopexin in the circulation. Also, some heme iron may be catabolized by heme oxygenase 1 (HO-1) to release non-heme iron and biliverdin. With second mechanism, heme iron is believed to be internalized by receptor mediated endocytosis which is degraded by HO-2 releasing non-heme iron and biliverdin. The non-heme iron then follows the path described previously [19] [21].

Compared to the non-heme iron, polymerization of heme iron is minimal in alkaline condition. Humic substances like tannins, phytates and chelators like desferrioxamine do not reduce heme bioavailability. This factor is important in Indian scenario where dietary iron bioavailability is poor due to phytate rich diets, inadequate dietary iron, and folate intake [22]. Presence of protein enhances

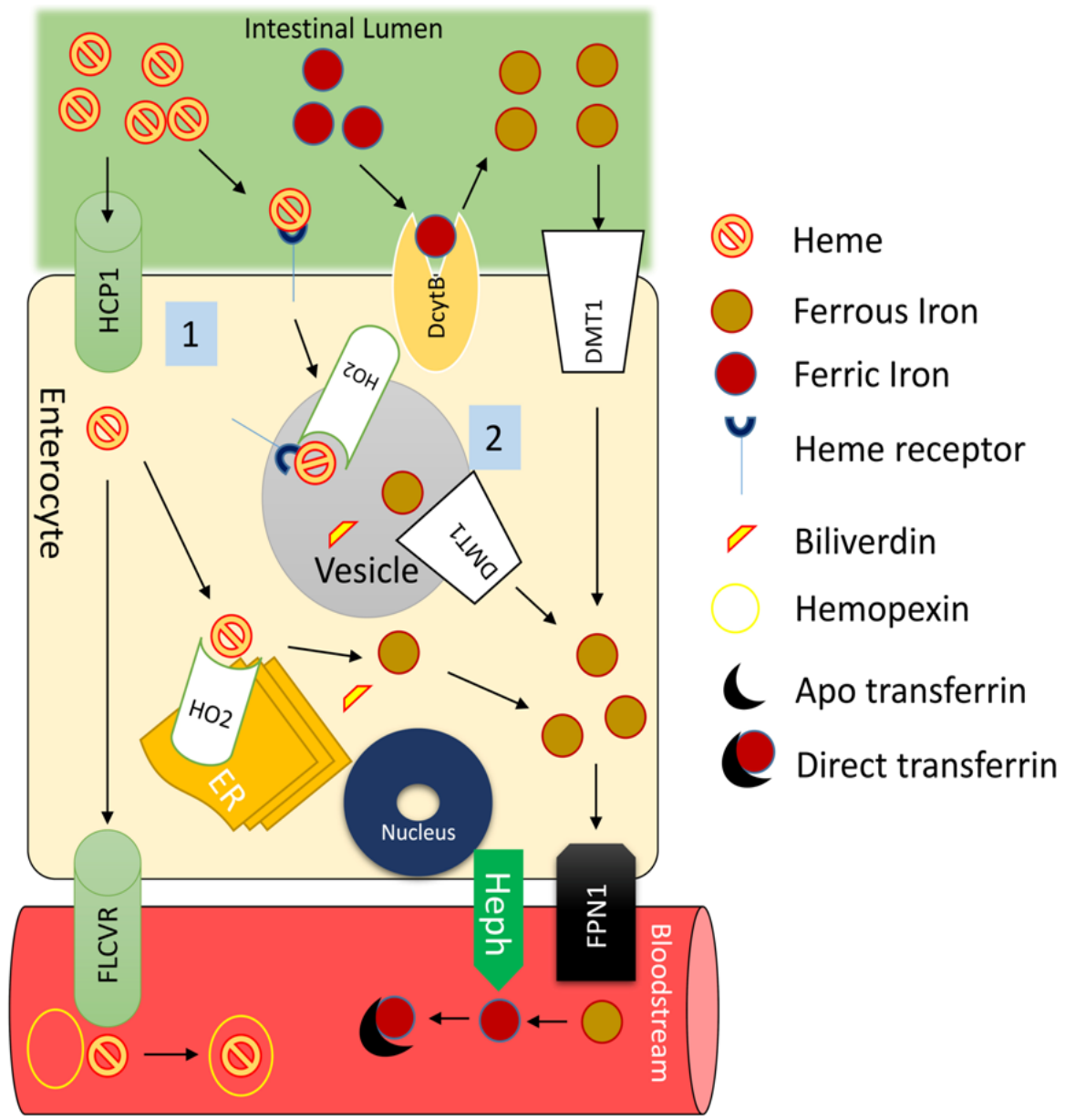

Figure 1. Schematic representation of heme and non-heme iron absorption mechanisms at enterocyte. 
absorption of heme iron. [4] This differentiation of iron as heme iron and non-heme iron is important. Seligman et al. [20] administered HIP, ferrous fumarate, and placebo with breakfast to patients. HIP led to increased iron absorption even with meal as compared to ferrous fumarate and placebo ( $\mathrm{p}<0.03$ and $\mathrm{p}<0.02$ respectively). Due to anticipated lack of gastrointestinal side effects, compliance might be better.

\subsection{Clinical Evidence}

Nam et al. [19] studied absorption efficiency of heme iron polypeptide (HIP) and iron salt preparation in Korean healthy volunteers. The objective was to investigate the absorption efficiency of heme-iron polypeptide and iron salt preparations available. They gave five different iron salts to volunteers in a double blind randomized fashion [Group I: HIPk12 (HIP produced in Korea - $12 \mathrm{mg}$ Iron), Group II: HIj12 (HIP produced in Japan - 12 mg Iron), Group III: Ferrous aminoacetate - 12 mg Iron, Group IV: Ferrous aminoacetate - $100 \mathrm{mg}$ Iron, Group V: Placebo group (12 mg glucose)]. Absorption of different salts was then compared. Intake of HIPk but not iron salt increased serum levels suggesting better absorption of HIP than iron-salts. Also, absorption of iron correlated with serum iron concentration. Significant increase in serum iron level was reported at 3 and 5 hours in patients with low serum iron levels $(<80 \mu \mathrm{g} / \mathrm{dL})$ than those with normal serum iron. But, whether such a benefit persists during the pregnancy was evaluated by Young et al. [23]. Intrinsically labelled ${ }^{58} \mathrm{Fe}$-heme and non-heme ${ }^{57} \mathrm{Fe}$ (ferrous sulphate) were administered to pregnant women in third trimester. Maternal and cord blood was collected at delivery. ${ }^{58} \mathrm{Fe}$ and ${ }^{57} \mathrm{Fe}$ levels were assessed as a function of maternal/neonatal iron status. Maternally absorbed ${ }^{58} \mathrm{Fe}$ tracer present in the neonates $(2.7 \pm 1.3)$ compared to the ${ }^{57} \mathrm{Fe}$ tracer $(2.2 \pm 1.4)$ was significantly greater $(\mathrm{p}=0.02)$ (Figure 2$)$. Also, transfer of $58 \mathrm{Fe}$ to the fetus was inversely associated with maternal $\mathrm{Hb}$ and maternal ferritin levels whereas total body iron significantly correlated with heme iron transfer. Further, net transfer of ${ }^{58} \mathrm{Fe}$ was directly associated with neonatal $\mathrm{Hb}$ and erythropoietin levels. This suggests that heme-iron administered to the mother may be favorably transported across the placenta to the fetus.

Young et al. [8] studied iron utilization with two stable oral isotopes $\left({ }^{57} \mathrm{Fe}\right.$ and ${ }^{58} \mathrm{Fe}$ ) in pregnant and non-pregnant women. Women were randomly assigned to receive both an animal-based heme meal (intrinsically labelled ${ }^{58} \mathrm{Fe}$ pork) and labelled ferrous sulphate $\left({ }^{57} \mathrm{Fe}\right)$ fed on alternate days. Blood samples obtained 2-week post dosing were used to assess iron status indicators, serum hepcidin and iron utilization based on RBC incorporation of iron isotopes. Heme-iron utilization was significantly higher relative to utilization of ferrous sulphate among both pregnant $(47.7 \% \pm 14.4 \%$ vs. $40.4 \% \pm 13.2 \%, \mathrm{p}=0.04)$ and non-pregnant women $(50.1 \% \pm 14.8 \%$ vs. $15.3 \% \pm 9.7 \%$, p $<0.0001)$.

In another clinical study, Suzuki et al. [24] evaluated the efficacy of BioIron-150 (Heme Iron Polypeptide $3 \mathrm{mg}$ ) in pregnancy and in females with bleeding disorder. Twenty-four pregnant women in third trimester (27 to 40 weeks of 


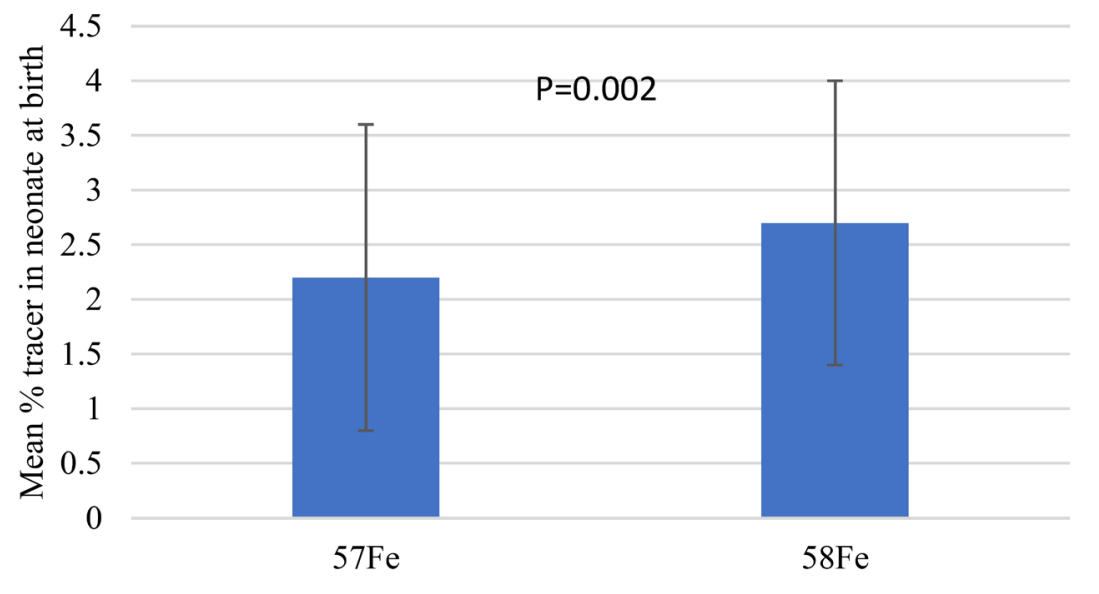

Error bars represent standard deviation $(\mathrm{n}=19)$

Figure 2. Percentage of maternally absorbed iron tracer in neonate assessed at birth.

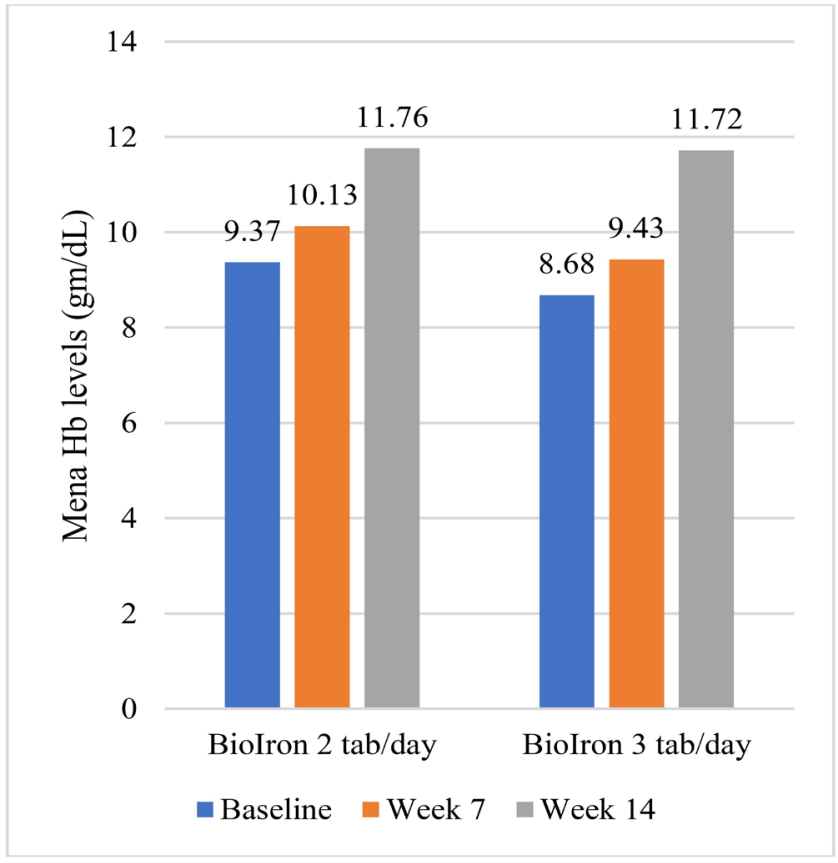

Figure 3. Change in $\mathrm{Hb}$ levels in two groups of patients from baseline to week 14.

gestation) were administered BioIron $150 \mathrm{mg}$ (equivalent to HIP $3 \mathrm{mg}$ ), two or three times a day depending on $\mathrm{Hb}$ and hematocrit levels. A gradual rise in $\mathrm{Hb}$ levels was observed over a 14-week period. Most patients' $\mathrm{Hb}$ reached above 11 $\mathrm{gm} / \mathrm{dL}$ with twice daily regime. Figure 3 shows the changes in $\mathrm{Hb}$ levels from baseline to 14 week. HIP improved and/or maintained $\mathrm{Hb}$ as well as hematocrit levels. Authors have suggested that average dose of $6.5 \mathrm{mg}$ elemental iron as HIP or maximum dose of $9 \mathrm{mg}$ elemental iron as HIP is sufficient to improve anemia in pregnant women when administered in the third trimester [24].

Eskeland et al. [25] conducted randomized, double blind trial to evaluate the effects of low dose iron supplementation ( $27 \mathrm{mg}$ of elemental iron daily), with and without a heme component, given in the second-half of pregnancy, on iron 
status in pregnancy and postpartum. Participants were randomized into three groups as follows. First group, the heme-iron $(\mathrm{HI})$ group $(n=31)$ received three tablets containing $1.2 \mathrm{mg}$ heme-iron plus $8 \mathrm{mg} \mathrm{Fe}^{2+}$ as iron fumarate per tablet and one placebo tablet, second group, the non-heme iron (Non-HI) group ( $\mathrm{n}=$ 30) received one tablet containing $27 \mathrm{mg} \mathrm{Fe}^{2+}$ as iron fumarate with $100 \mathrm{mg}$ vitamin $\mathrm{C}$ and three placebo tablets and third, the placebo group $(\mathrm{n}=29)$ received four placebo tablets. Postpartum, $\mathrm{Hb}$ of significant $(\mathrm{p}<0.05)$ number of women fell below $11 \mathrm{gm} / \mathrm{dL}$ in placebo group (52\%) than in the supplemented group $(25 \%)$. In the postpartum period, $\mathrm{Hb}<10 \mathrm{gm} / \mathrm{dL}$ was not found in any women in iron supplemented group as against in 14\% women receiving placebo. Also, empty iron stores in heme-iron supplemented group in postpartum phase were found in only $8 \%$ women than those in $14 \%$ women in pregnant state whereas there was significant increase in number of women with empty iron stores in postpartum period in non-heme iron group (from 3\% to 27\%) as well as in placebo group (from $21 \%$ to $52 \%$ ). Ten percent of the HI, $20 \%$ of the Non-HI and $45 \%$ of the placebo group, failed to maintain an acceptable hematologic status. This consolidates the findings of other studies. Heme iron supplementation not only improves iron status but also helps in maintenance of iron levels in the post-partum period.

Heme iron absorption is regulated by heme receptor and body iron levels as against non-heme iron salts. Nam et al. [19] in their study have observed that there was significant increase in serum iron levels in subjects supplemented with HIP who had low initial serum iron levels $(<80 \mu \mathrm{g} / \mathrm{dl})$. But same was not evident in those who had normal initial iron levels. Seligman et al. [20] has noted similar findings but they had taken serum ferritin levels as a marker of body iron store. They observed that continual supplementation of heme-iron may not lead to iron overload. This is an important finding wherein the possibility of iron overload with higher intake or overuse of conventional iron salt can be avoided with use of heme-iron supplements instead. Findings of Young et al. [8] suggest that heme iron utilization is not significantly influenced by iron stores or serum hepcidin. Iron utilization correlated with serum hepcidin levels but role of hepcidin in heme-iron utilization is not as clearly understood as compared to non-heme iron utilization. A recent evaluation from Abdelazim et al. [26] compared HIP (oral Proferrin ${ }^{\circledR}$-ES) and intravenous iron saccharate complex (Ferrosac) in 206 pregnant women with iron deficiency anemia $(\mathrm{Hb}<10 \mathrm{gm} / \mathrm{dL})$. At the end of 3 -months treatment, $\mathrm{Hb}$ increased from $8.5 \pm 3.5$ to $11.3 \pm 1.3 \mathrm{gm} / \mathrm{dl}$ in HIP treatment and from $8.7 \pm 2.5$ to $11.7 \pm 0.9 \mathrm{gm} / \mathrm{dl}$ in IV iron treatment. Ferritin level also increased in two groups. There were no significant differences in two groups for change in $\mathrm{Hb}$ or ferritin levels. GI upset was reported in $1.6 \%$ of patients receiving oral HIP. Study reported oral HIP as effective and tolerable treatment. Thus, HIP can be considered as an alternative to intravenous iron saccharate complex for iron deficiency anemia of pregnancy.

\subsection{Safety}

Suzuki et al. [24] reported HIP as a safe and effective supplement in pregnant 
women. None of the subject experienced any unexpected adverse events and there were no drop outs due to the same. Hoppe et al. [17] investigated the efficacy of heme iron in the form of blood-based crisp bread as a diet-based treatment program against non-heme iron supplementation to improve the iron status of women of reproductive age. They reported that diet-based treatment has few side effects and worth to be used to improve iron status of women. Seligman et al. [20] checked for safety of heme-iron supplementation with questionnaire based investigation. No patients from heme-iron group had any side effects. Eskeland et al. [25] also has noted similar findings in terms of compliance. Less than $50 \%$ compliance with treatment was $4 \%$ in heme-iron group, $12 \%$ in nonheme iron group and $5 \%$ in placebo group.

Essentially, any adverse drug reaction can directly affect compliance of the patient. Ekstrom et al. [27] observed limited adherence to iron supplementation as a major reason for the lower effectiveness of anemia prevention programs. They found that among women at 21 - 26 week of gestation, adherence in gastric delivery system (GDS) iron supplement group was $61 \%$ compared with $42 \%$ for the conventional iron supplement group. In both groups, women experiencing side effects had about one third lower adherence. Habib et al. [28] in their study compared the outcome of $\mathrm{Hb}$ levels in 308 pregnant women near term with their compliance to iron supplementation during initial pregnancy. Hb levels improved significantly only amongst strictly compliant pregnant women. Anemia was significantly associated with noncompliance with iron supplementation, the adjusted OR was 6.19 (95\% CI 2.55 - 15.02, p < 0.0001). Known association of oral non-heme iron therapy with gastro-intestinal intolerance and interaction with food hampering its absorption are limiting factors to implement guidelines of iron supplementation in pregnant women. [29] [30] Good tolerance to hemeiron supplementation would maximize compliance to its routine administration and hence improve significantly the maternal and fetal iron store and $\mathrm{Hb}$ levels. Table 1 summarizes current evidence from these studies.

\subsection{Current Status}

Heme-iron is used as supplement to treat iron deficient states and to improve and maintain iron stores in pregnant women. Higher bioavailability compared to non-heme iron makes it a suitable choice as a supplement for iron deficiency anemia. It is especially useful in patients who have low compliance to the non-heme iron therapy (iron salts like ferrous sulphate) due to gastro-intestinal intolerance. Also, it is useful where parenteral iron is contraindicated or cannot be used for any other reasons. Superior tolerability provides added advantage with heme-iron. Compliance to the iron therapy is the single-most important factor that has been identified as obstacle to effective treatment of iron deficiency anemia. Thus, it can be recommended and used as a first choice of iron supplementation in iron deficiency anemia in pregnancy to improve iron and maintain maternal iron stores, to improve neonatal iron stores, through effective and safe therapy with sustained compliance over long term. The Korean food 
Table 1. Summary of clinical evidence on heme iron in pregnancy.

\begin{tabular}{|c|c|c|c|}
\hline Authors & Population & Intervention & Pregnancy state related major findings \\
\hline $\begin{array}{l}\text { Nam et al. } \\
{[19]}\end{array}$ & $\begin{array}{l}\text { Healthy volunteers } \\
(\mathrm{n}=56)\end{array}$ & $\begin{array}{l}\text { HIP and iron salts available in } \\
\text { Korea ( } 5 \text { different preparations }{ }^{\star} \text { ) }\end{array}$ & $\begin{array}{l}\text { Intake of HIPk but not iron salt increased serum iron levels } \\
\text { Significant increase in iron levels at } 3 \text { and } 5 \text { hours in patients } \\
\text { with iron }<80 \mu \mathrm{g} / \mathrm{dL}\end{array}$ \\
\hline $\begin{array}{l}\text { Young } \\
\text { et al. }[23]\end{array}$ & $\begin{array}{l}\text { Pregnant women }\left(3^{\text {rd }}\right. \\
\text { trimester })(\mathrm{n}=19)\end{array}$ & $\begin{array}{l}\text { labelled }{ }^{58} \mathrm{Fe} \text {-heme and non-heme } \\
{ }^{57} \mathrm{Fe} \text { (ferrous sulphate) }\end{array}$ & $\begin{array}{l}{ }^{58} \mathrm{Fe} \text { tracer to neonate } \\
\text { - } \\
\text { - } \\
\text { - } \\
\text { - } \\
\text { Digniferect associantly higher than }{ }^{57} \mathrm{Fe} \\
\text { levels }\end{array}$ \\
\hline $\begin{array}{l}\text { Young } \\
\text { et al. [8] }\end{array}$ & $\begin{array}{l}\text { Pregnant }(\mathrm{n}=18) \text { and } \\
\text { non-pregnant } \\
(\mathrm{n}=11)\end{array}$ & $\begin{array}{l}\text { animal-based heme meal }\left({ }^{58} \mathrm{Fe}\right. \\
\text { pork) and ferrous sulphate }\left({ }^{57} \mathrm{Fe}\right) \\
\text { fed on alternate days }\end{array}$ & $\begin{array}{l}\text { Heme-iron utilization was significantly higher compared to } \\
\text { ferrous sulphate in } \\
\text { - pregnant }(47.7 \% \pm 14.4 \% \text { vs. } 40.4 \% \pm 13.2 \%, \mathrm{p}=0.04) \\
\text { - } \text { non-pregnant women }(50.1 \% \pm 14.8 \% \text { vs. } 15.3 \% \pm 9.7 \%, \mathrm{p}< \\
0.0001)\end{array}$ \\
\hline $\begin{array}{l}\text { Suzuki } \\
\text { et al. }[24]\end{array}$ & $\begin{array}{l}\text { Pregnant and } \\
\text { lactating }(\mathrm{n}=24) / \\
\text { with bleeding } \\
\text { disorder }(\mathrm{n}=12)\end{array}$ & $\begin{array}{l}\text { HIP } 3 \text { mg, BD or TID based on } \mathrm{Hb} \\
\text { levels }\end{array}$ & $\begin{array}{l}\text { Gradual increase in } \mathrm{Hb} \text { over } 14 \text {-week period } \\
\text { Mean } \mathrm{Hb} \text { change in pregnant women } \\
\text { - } \quad 2 \mathrm{tab} / \mathrm{d} \text { : from } 9.37 \mathrm{gm} / \mathrm{dL} \text { at day } 0 \text { to } 11.76 \mathrm{gm} / \mathrm{dL} \text { at week } 14 \\
\text { - } \quad 3 \mathrm{tab} / \mathrm{d} \text { : from } 8.68 \mathrm{gm} / \mathrm{dL} \text { at day } 0 \text { to } 11.72 \mathrm{gm} / \mathrm{dL} \text { at week } 14 \\
\text { Improvement and/or maintenance of } \mathrm{Hb} \text { and hematocrit } \\
\text { No unexpected adverse events } \\
\text { No drop outs from study }\end{array}$ \\
\hline $\begin{array}{l}\text { Eskeland } \\
\text { et al. }[25]\end{array}$ & Pregnant $(n=90)$ & $\begin{array}{l}\text { low dose ( } 27 \mathrm{mg} \text { of elemental iron } \\
\text { daily), } \pm \text { heme component: } 3 \\
\text { groups - heme-iron (HI), } \\
\text { non-heme iron (Non-HI) and } \\
\text { placebo }\end{array}$ & $\begin{array}{l}\text { Empty iron stores in postpartum phase } \\
\text { - HI: reduced to } 8 \% \text { from } 14 \% \text { in pregnant state } \\
\text { - } \text { Non-HI: increased to } 27 \% \text { from } 3 \% \\
\text { - } \quad \text { Placebo: increased to } 52 \% \text { from } 21 \% \\
\text { Compliance of below } 50 \% \\
\text { - HI: } 4 \% \text { women } \\
\text { - Non-HI: } 12 \% \text { women } \\
\text { - } \quad \text { Placebo: } 5 \% \text { women }\end{array}$ \\
\hline $\begin{array}{l}\text { Abdelazim } \\
\text { et al. }[26]\end{array}$ & Pregnant $(n=260)$ & $\begin{array}{l}\text { Proferrin }{ }^{\circledR} \text {-ES oral ( } 11 \mathrm{mg} \text { of HIP) } \\
\text { vs. Ferrosac IV ( } 200 \mathrm{mg} \text { of iron } \\
\text { saccharate complex) }\end{array}$ & $\begin{array}{l}\text { Increase in Hb after } 3 \text {-month treatment } \\
\text { - Oral HIP: } 8.5 \pm 3.5 \text { to } 11.3 \pm 1.3 \mathrm{gm} / \mathrm{dL} \\
\text { - IV iron: } 8.7 \pm 2.5 \text { to } 11.7 \pm 0.9 \mathrm{gm} / \mathrm{dL} \\
\text { - No significant difference in two groups } \\
\text { Increase in ferritin after } 3 \text {-month treatment } \\
\text { - Oral HIP: } 19.4 \pm 4.9 \text { to } 118.8 \pm 7.1 \mathrm{ug} / \mathrm{L} \\
\text { - } \quad \text { IV iron: } 15.3 \pm 5.6 \text { to } 122.3 \pm 6.4 \mathrm{ug} / \mathrm{L} \\
\text { - No significant difference in two groups }\end{array}$ \\
\hline
\end{tabular}

${ }^{*}$ see text for details.

and drugs administration, Korea food additives code identifies heme iron as a natural additive and is available in Korea [31]. Health Canada approved hemeiron in 2007 [32].

\section{Conclusion}

Heme-iron promises a better source of iron for iron deficiency and anemic states. Superior bioavailability due to the unique mechanism of absorption and absence of significant gastrointestinal side effects has made it a preferred choice in anemia of pregnancy. Compliance hinders effective management of iron-de- 
ficiency anemia wherein heme-iron promises improved compliance. It is even bioavailable when taken with meal. Adherence to HIP helps restores iron balance effectively during and after pregnancy. Effective transport of heme iron across placenta can help improve iron stores and hemoglobin levels in neonates too. Supplementation during the latter half of pregnancy compensates effectively for the iron loss in the early postpartum period and probably averts the development of severe anemia in the postpartum period. Heme iron thus is a promising supplementary treatment for iron deficiency states in pregnancy.

\section{Acknowledgements}

Authors thank and acknowledge Dr. Vijay M Katekhaye (Quest MedPharma Consultants, Nagpur, India) for his assistance on drafting the manuscript.

\section{Conflict of Interests}

Sugandh Goel, Amandeep Singh Khurana, Amit Qamra, Salman Motlekar, Hanmant Barkate are salaried employees of Wockhardt Ltd., Mumbai, India. Other authors declare no conflicts of interests.

\section{References}

[1] WHO (2011) Hemoglobin Concentrations for the Diagnosis of Anemia and Assessment of Severity. Vitamin and Mineral Nutrition Information System. World Health Organization, Geneva. (WHO/NMH/NHD/MNM/11.1) http://apps.who.int/iris/bitstream/10665/85839/3/WHO_NMH_NHD_MNM_11.1_ eng.pdf?ua $=1$

[2] Bothwell, T.H. (2000) Iron Requirements in Pregnancy and Strategies to Meet Them. The American Journal of Clinical Nutrition, 72, 257s-264s.

[3] Allen, L.H. (2000) Anemia and Iron Deficiency: Effects on Pregnancy Outcome. The American Journal of Clinical Nutrition, 71, 1280s-1284s.

[4] Milman, N. (2006) Iron and Pregnancy-A Delicate Balance. Annals of Hematolo$g y$, 85, 559-565. https://doi.org/10.1007/s00277-006-0108-2

[5] (2011) Good Clinical Practice Recommendations for Iron Deficiency Anemia in Pregnancy (IDA) in Pregnancy in India. The Journal of Obstetrics and Gynecology of India, 61, 569-571. https://doi.org/10.1007/s13224-011-0097-5

[6] Pavord, S., Myers, B., Robinson, S., Allard, S., Strong, J. and Oppenheimer, C. (2012) UK Guidelines on the Management of Iron Deficiency in Pregnancy. British Journal of Hematology, 156, 588-600. https://doi.org/10.1111/j.1365-2141.2011.09012.x

[7] Johnson-Wimbley, T.D. and Graham, D.Y. (2011) Diagnosis and Management of Iron Deficiency Anemia in the 21st Century. Therapeutic Advances in Gastroenterology, 4, 177-184. https://doi.org/10.1177/1756283x11398736

[8] Young, M.F., Griffin, I., Pressman, E., McIntyre, A.W., Cooper, E., McNanley, T., Harris, Z.L., Westerman, M. and O'Brien, K.O. (2010) Utilization of Iron from an Animal-Based Iron Source Is Greater than That of Ferrous Sulfate in Pregnant and Nonpregnant Women. The Journal of Nutrition, 140, 2162-2166. https://doi.org/10.3945/jn.110.127209

[9] EFSA Panel on Food Additives and Nutrient Sources added to Food (ANS) (2010) 
Scientific Opinion on the Safety of Iron (Blood Peptonates) for the Proposed Uses as a Source of Iron Added for Nutritional Purposes to Foods for the General Population, Including Food Supplements. EFSA Journal, 8, 1585. www.efsa.europa.eu

[10] Nissenson, A.R. and Charytan, C. (2003) Controversies in Iron Management. Kidney International, 64, S64-S71. https://doi.org/10.1046/j.1523-1755.64.s87.10.x

[11] Prevalence of Anemia among Pregnant Women (\%). http://data.worldbank.org/indicator/SH.PRG.ANEM?locations=IN

[12] Bora, R., Sable, C., Wolfson, J., Boro, K. and Rao, R. (2014) Prevalence of Anemia in Pregnant Women and Its Effect on Neonatal Outcomes in Northeast India. The Journal of Maternal-Fetal \& Neonatal Medicine, 27, 887-891. https://doi.org/10.3109/14767058.2013.845161

[13] Vemulapalli, B. and Rao, K.K. (2014) Prevalence of Anemia among Pregnant Women of Rural Community in Vizianagram North Costal Andhra Pradesh, India. AJMS, 5, 21-25.

[14] Chandra, S., Tripathi, A.K., Mishra, S., Amzarul, M. and Vaish, A.K. (2012) Physiological Changes in Hematological Parameters during Pregnancy. Indian Journal of Hematology and Blood Transfusion, 28, 144-146. https://doi.org/10.1007/s12288-012-0175-6

[15] Indian Council for Medical Research (2011) Dietary Guidelines for Indians-A Manual. 2nd Edition, National Institute of Nutrition, Hyderabad, India, 89. http://ninindia.org/dietaryguidelinesforninwebsite.pdf

[16] Datta, S., Kodali, B. and Segal, S. (2010) Maternal Physiological Changes during Pregnancy, Labor and Postpartum Period. In: Obstetric Anesthesia Handbook, Springer, New York, 1-14. https://doi.org/10.1007/978-0-387-88602-2_1

[17] Hoppe, M., Brün, B., Larsson, M.P., Moraeus, L. and Hulthén, L. (2013) Heme Iron-Based Dietary Intervention for Improvement of Iron Status in Young Women. Nutrition, 29, 89-95. https://doi.org/10.1016/j.nut.2012.04.013

[18] Nagaraju, S.P., Cohn, A., Akbari, A., Davis, J.L. and Zimmerman, D.L. (2013) Iron Polypeptide for the Treatment of Iron Deficiency Anemia in Non-Dialysis Chronic Kidney Disease Patients: A Randomized Controlled Trial. BMC Nephrology, 14, 64. http://www.biomedcentral.com/1471-2369/14/64 https://doi.org/10.1186/1471-2369-14-64

[19] Nam, T., Shim, J.Y., Kim, B., Rah, S.Y., Park, K., Kim, S., Mun, E.G., Jeong, Y.J., Han, M.K., Cha, Y.S., Chae, S.W., Im, M.J. and Kim, U.H. (2006) Clinical Study on the Iron Absorption from Heme-Iron Polypeptide and Nonheme-Iron. Nutritional Sciences, 9, 295-300.

[20] Seligman, P.A., Moore, G.M. and Schleicher, R.B. (2000) Clinical Studies of HIP: An Oral-Iron Product. Nutrition Research, 20, 1279-1286.

[21] West, A.R. and Oates, P.S. (2008) Mechanisms of Iron Absorption: Current Questions and Controversies. World Journal of Gastroenterology, 14, 4101-4110. https://doi.org/10.3748/wjg.14.4101

[22] Kalaivani, K. (2009) Prevalence \& Consequences of Anemia in Pregnancy. Indian Journal of Medical Research, 130, 627-633.

[23] Young, M.F., Griffin, I., Pressman, E., McIntyre, A.W., Cooper, E., McNanley, T., Harris, Z.L., Westerman, M. and O’Brien, K.O. (2012) Maternal Hepcidin Is Associated with Placental Transfer of Iron Derived from Dietary and Non-Sources. The Journal of Nutrition, 142, 33-39. https://doi.org/10.3945/jn.111.145961

[24] Suzuki, S., Ito, H. and Kiyokawa, H. (1990) The Effect of BioIron-150 on Pregnant Women and Women with Females Associated Bleeding Disorders. The World of 
Obstetrics and Gynecology, 42, 33-42.

[25] Eskeland, B., Malterud, K., Ulvik, R.J. and Hunskaar, S. (1997) Iron Supplementation in Pregnancy: Is Less Enough? A Randomized, Placebo Controlled Trial of Low Dose Iron Supplementation with and without Iron. Acta Obstetricia et Gynecologica Scandinavica, 76, 822-828. https://doi.org/10.3109/00016349709024359

[26] Abdelazimn, I.A., Abu-Faza, M., Elbiaa, A.A.M., Othman, H.S., Alsharif, D.A. and Elsawah, W.F. (2017) Heme Iron Polypeptide (Proferrin ${ }^{\circledR}$-ES) versus Iron Saccharate Complex (Ferrosac) for Treatment of Iron Deficiency Anemia during Pregnancy. Acta Medica International, 4, 55-60.

[27] Ekström, E.C., Kavishe, F.P., Habicht, J.P., Frongillo, E.A., Rasmussen, K.M. and Hemed, L. (1996) Adherence to Iron Supplementation during Pregnancy in Tanzania: Determinants and Hematologic Consequences. The American Journal of Clinical Nutrition, 64, 368-374.

[28] Habib, F., Habib, Z.A.E., Alenazy, M. and Nooh, R. (2009) Compliance to Iron Supplementation during Pregnancy. Journal of Obstetrics and Gynaecology, 29, 487-492. https://doi.org/10.1080/01443610902984961

[29] Khalafallah, A.A. and Dennis, A.E. (2012) Iron Deficiency Anemia in Pregnancy and Postpartum: Pathophysiology and Effect of Oral versus Intravenous Iron Therapy. Journal of Pregnancy, 2012, Article ID: 630519. https://www.hindawi.com/journals/jp/2012/630519/

[30] Short, M.W. and Domagalski, J.E. (2013) Iron Deficiency Anemia: Evaluation and Management. American Family Physician, 87, 98-104.

[31] Ministry of Food and Drug Safety, Korea Food Additives Code. II. Article 3. Standards and Specification, B. Natural Additives, 121. Heme Iron. pp. 1378-1380. http://www.mfds.go.kr/fa/ebook/egongjeon_intro.jsp

[32] Iron Polypeptide $\left(\right.$ Proferrin $^{\circledR}$ ) versus Oral and Injectable Iron Products for the Treatment of Anemia. https://www.cadth.ca/heme-iron-polypeptide-versus-oral-and-injectable-iron-prod ucts-treatment-anemia

\section{Scientific Research Publishing}

Submit or recommend next manuscript to SCIRP and we will provide best service for you:

Accepting pre-submission inquiries through Email, Facebook, LinkedIn, Twitter, etc. A wide selection of journals (inclusive of 9 subjects, more than 200 journals)

Providing 24-hour high-quality service

User-friendly online submission system

Fair and swift peer-review system

Efficient typesetting and proofreading procedure

Display of the result of downloads and visits, as well as the number of cited articles

Maximum dissemination of your research work

Submit your manuscript at: http://papersubmission.scirp.org/

Or contact ojog@scirp.org 